\title{
Enzyme-based approaches to control microbial biofilms in dairy processing environments: A review
}

\author{
S. F. Gonçalves ${ }^{1}$, S. H. I. Lee ${ }^{1}$, A. Mousavi Khaneghah ${ }^{2}$, C. A. F. Oliveira ${ }^{1 *}$ \\ ${ }^{1}$ Department of Food Engineering, School of Animal Science and Food Engineering, University of São Paulo, Pirassununga, \\ SP, Brazil; ${ }^{2}$ Department of Food Science, Faculty of Food Engineering, State University of Campinas, Campinas, SP, Brazil
}

"Corresponding Author: C. A. F. Oliveira, Department of Food Engineering, School of Animal Science and Food Engineering, University of São Paulo, Pirassununga, SP, Brazil. Email: carlosaf@usp.br

Received: 21 October 2020; Accepted: 18 November 2020; Published: 21 December 2020

(c) 2020 Codon Publications

OPEN ACCESS (C) (i) () ()

REVIEW ARTICLE

\begin{abstract}
In this review, formation of biofilms and the available data on enzyme-based preparations to control microbial biofilms in dairy processing environments are presented. Mature biofilms, especially those formed by pathogenic bacteria, have increased resistance to biocides, hence stressing the importance of stringent hygienic procedures. Proteases, amylases, cellulases and DNAses are among the most recently studied enzymes that could be associated with the main biocides used in the dairy industry to increase the effect of removal of biofilm. However, additional studies should be conducted to select the best cost-benefit combinations of selected enzymes and biocides to remove efficiently biofilms in dairy processing environments.
\end{abstract}

Keywords: biofilm; enzyme-based preparations; industrial hygiene; surface contamination

\section{Introduction}

Contaminated surfaces that have been exposed to food are potential sources of transmitting pathogenic or deteriorating microorganisms in food processing and at handling sites. Microorganisms can be found on the surfaces of equipment and utensils in the form of planktonic or sessile cells, which may form biofilms that increase the risk of food contamination (Fleming et al., 2016). Biofilms are defined as communities of microorganisms, of sessile microbial life, with adhesion to solid supports and production of extracellular polymeric substances (EPS), representing about $50-95 \%(\mathrm{w} / \mathrm{w})$, thus ensuring cell protection (Hooshdar et al., 2020). Biofilms can contain many bacterial and fungal cells that may coexist and establish a cooperative/aggressive phenotype in which they can form a three-dimensional layer or structure (Oxaran et al., 2018). Biofilms are considered as highly organised forms, allowing the exchange of nutrients and metabolics in the same ecosystem in order to guarantee survival (Shiand Zhu, 2009). Among foodborne microorganisms that form biofilms on surfaces (Figure 1),
Staphylococcus aureus (Lee et al., 2014), Bacillus cereus (Ehling-Schulz et al., 2019; Gopal et al., 2015), Listeria monocytogenes (Lee et al., 2017a), Escherichia coli (Cherif-Antar et al., 2016), Salmonella spp. (Wang et al., 2016) and Pseudomonas spp. (Cherif-Antar et al., 2016; Rossi et al., 2018) are of major importance for the dairy industry because of their frequent occurrence and potential health and economic effects.

S. aureus is a Gram-positive coccus, anaerobic facultative, coagulase and catalase positive bacterium and is considered as one of the main causes of bacterial foodborne diseases in humans (Gutiérrez et al., 2012). Food poisoning by $S$. aureus is characterised by symptoms such as nausea, vomiting, cramps and diarrhoea, which can be triggered if concentration of $S$. aureus in food is more than $10^{5}$ colony forming units/gram (CFU/g) (Jamali et al., 2015). S. aureus is often found in milk and dairy products, which are excellent substrates for the growth of the pathogen (Lee et al., 2014). B. cereus is a rod-shaped, facultative aerobic and Gram-positive bacterium that can form spores, with significant impact on human health 


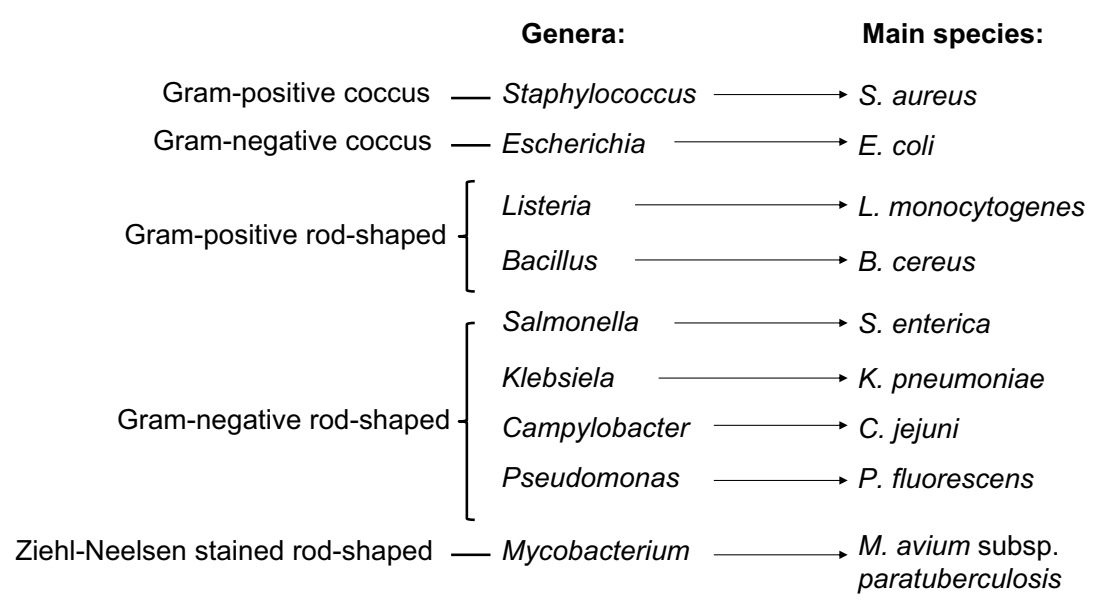

Figure 1. Main biofilm-forming pathogenic microorganisms found in dairy processing environments.

as a causative agent of foodborne diseases (OwusuKwarteng et al., 2017). Dairy foods contaminated with $B$. cereus are among the most frequent vehicles of its toxins responsible for diarrhoeal or emetic syndromes (Vidic et al., 2020). The diarrheal syndrome caused by B. cereus is characterised by abdominal pain, watery diarrhoea and rectal tenesmus, which develop between 8 and $16 \mathrm{~h}$ of eating contaminated foods containing levels above $10^{5}$ CFU/g (Bottone, 2010). The concentration required for developing emetic syndrome is around $10^{7} \mathrm{CFU} / \mathrm{g}$, which is characterised by nausea and vomiting after 1 to $5 \mathrm{~h}$ of ingestion of contaminated food (Bottone, 2010).

L. monocytogenes is another Gram-positive, rod-shaped bacterium found in milk and dairy products that causes human diseases, including listeriosis, after consuming contaminated foods (Akrami-Mohajeri et al., 2018). L. monocytogenes causes meningitis, endocarditis, encephalitis, septicemia, spontaneous abortion, immune depression and death in extreme cases (Rodríguez-López et al., 2018). Several risk assessments have concluded that levels $>10^{6} \mathrm{CFU} / \mathrm{g}$ are responsible for the majority of cases of invasive listeriosis (Ryser, 2011). L. monocytogenes has been reported in raw milk of cow, sheep and goat (Mansouri-Najand et al., 2015) as well as in readyto-eat dairy products such as cheese (Jakobsen et al., 2011) and ice cream (Chen et al., 2016). Other bacteria frequently found in milk and dairy products, with economic and health interest, as well as biofilm formation ability, include several species of Pseudomonas such as P. fluorescens (Meng et al., 2017), Klebsiela pnemoniae (Mohamed et al., 2018), Mycobacterium avium subsp. paratuberculosis (Mullan, 2019), Campylobacter jejuni (Song et al., 2020), S. enterica and E. coli O157:H7 (Ahmed and Shimamoto, 2014).

Since biofilms are formed, dispersed, and then reformed on the same surface with the remains of the previously formed biofilms, regular and effective cleaning methods are usually useful to prevent bacterial cells' initial adhesion on surfaces in the dairy industry. For this reason, food quality programmes, such as Good Manufacturing Practices, Sanitation Standard Operating Procedures, and Hazard Analysis and Critical Control Points, are fundamental tools to ensure effective cleaning and disinfection in food production environments (Cusato et al., 2014), thus avoiding the adhesion of bacterial cells and subsequent formation of biofilms on surfaces (Dominciano et al., 2016). In this context, the process of cleaning-inplace (CIP) is considered a central point in the biofilm control, provided that sanitisers are used to ensure the inactivation of microorganisms (Srey et al., 2013). The correct application of biocides during the CIP process is crucial for reducing the bacterial load at the end of the disinfection procedure (Dominciano et al., 2016). However, pipe connections, valves and other places with difficult access for biocides are the main obstacles for proper cleaning of dairy processing lines, thus representing potential biofilm formation (Marchand et al., 2012). Moreover, microorganisms adhered to surfaces after biofilm formation are more resistant to biocides, such as chlorine, than non-adherent microorganisms (Lee et al., 2016, 2017b).

In food processing environments, bacterial species typically reside in mixed-species biofilm, leading to several interactions among species, which markedly influence the growth of biofilms (Oxaran et al., 2018). In this context, microorganisms that often co-occur in dairy environments such as some species from the genera Lactobacillus and Streptococcus have been tested regarding their potential anti-biofilm activity (Jeong et al., 2018). In addition, biofilms formed by L. rhamnosus GG were successfully used for detoxification of aflatoxin $M_{1}$ in milk (Assaf et al., 2019). Yeganeh et al. (2017) reported that L. plantarum, L. casei and L. acidophilus were effective against a ciprofloxacin-resistant uropathogenic 
strains of E. coli in pasteurised milk, resulting in an inhibitory effect on formation of its biofilm. According to Kim et al. (2019), the use of bacteriocins produced by $L$. brevis significantly reduced biofilms formed by $E$. coli and S. enterica serovar Typhimurium, mainly in the initial stages of biofilm formation. However, practical applications of microorganisms against biofilms formed by foodborne pathogens in real food processing environments have not been assessed.

In recent years, several research works have demonstrated that some enzyme-based preparations are effective against microbial biofilms on surfaces by degrading the biofilm matrix components (Coughlan et al., 2016). Nahar et al. (2018) published an extensive review of the enzyme-based biofilm impairment strategies with potential food industry applications. The scientific interest in these issues has markedly increased in the past years, leading to newly published data on enzyme-based approaches to tackle the biofilm problem. This article aims to review the biofilm formation and the recently published data on enzyme-based preparations to control biofilms formed by pathogenic bacteria in dairy processing environments.

\section{Biofilm formation and structure}

The formation and development of biofilms on surfaces depend on several factors, such as the type of surface material, $\mathrm{pH}$, temperature and availability of organic and inorganic materials (Di Ciccio et al., 2015; Fleming et al., 2016; Srey et al., 2013). Biofilms have a porous structure with channels where water and nutrients are distributed, providing a homogeneous architecture of the environment that ensures a consistent growth with effective transport of water, nutrients and oxygen to its interior (Oxaran et al., 2018). The formation of biofilms begins on surfaces when nutrients are available, and the first stage of formation is considered as adhesion of microorganisms through the matrix of exopolysaccharides favouring the appearance of microcolonies (Lee et al., 2016). The irreversible adhesion stage results from high specificity and short-distance interactions between pili, flagella and EPS production, by which dipole-dipole interaction bonds, hydrogen bonds, covalent and ionic bonds are strengthened (Høiby, 2017). These factors provide initial adhesion onto surfaces, leading to the beginning of cell mass growth, which ultimately forms bacterial biofilm (Cherif-Antar et al., 2016; Marchand et al., 2012). The biofilm assumes an organised flat or mushroom shape during the maturation stage, depending on the source of nutrients found on the surfaces (Srey et al., 2013). The period between formation and maturation of biofilms is variable, usually between 3 and 6 days after the initial adhesion stage (Nahar et al., 2018). Dispersion is the last stage in the biofilm cycle, allowing cells to detach and initiate a new cycle. Detachment occurs due to internal processes, such as the release of endogenous enzymes and EPS (Srey et al., 2013).

Among foodborne pathogens, adhesion of B. cereus is attributed to its hydrophobic characteristics (EhlingSchulz et al., 2019). In addition, B. cereus biofilms can behave as nests for the formation and release of spores in food-producing environments, which are difficult to eradicate since the spores are enveloped by the matrix adhered to guarantee its complete germination, thus making it resistant to sanitising agents (Kwon et al., 2017). The ability of S. aureus to form biofilms is also an important virulence factor since this mechanism guarantees its survival in a new environment (Watters et al., 2016). Materials such as stainless steel, glass and polypropylene have proven to be the sources of contamination by $S$. aureus after undergoing adhesion and subsequently forming biofilms (Lee et al., 2014; Unlu et al., 2018). L. monocytogenes is another pathogenic bacterium whose biofilms represent a significant problem in dairy processing areas, mainly because of the contamination of food handling surfaces, equipment and pipes (Kadam et al., 2013). Formation of biofilms of $L$. monocytogenes depends on several factors, such as $\mathrm{pH}$, surface material for adhesion, availability of inorganic or organic matter, resistance to adhesion and temperature (Lee et al., 2017a, 2017b). According to Silva and De Martinis (2013), L. monocytogenes can adhere and form biofilms at a cell concentration of $10^{4}-10^{7} \mathrm{UFC} / \mathrm{cm}^{2}$. Moreover, Colagiorgi et al. (2017) and Oxaran et al. (2018) demonstrated that $L$. monocytogenes could form mixed-species biofilms with S. aureus Flavobacterium spp. on stainless steel surfaces widely used in the dairy industry. In another study, Alonso and Kabuki (2019) observed a dominant behaviour of Enterococcus faecalis in mono-species, as well as in multi-species, biofilms with $L$. monocytogenes, S. aureus and B. cereus on stainless steel surfaces at $25^{\circ} \mathrm{C}$.

Cleaning and disinfection procedures using proper biocides are usually effective against initial stages of biofilms formed by pathogenic bacteria (Lee et al., 2017a). The main types of biocides used in the dairy industry include halogenic compounds, peroxygen, organic acids and quaternary ammonia. Importantly, these compounds' effectiveness, among other factors, depends on the initial bacterial load, application time, type of surface and spectrum against the microorganism (Dominciano et al., 2016). It has been demonstrated that chlorine-based sanitisers were effective against $L$. monocytogenes biofilms because of rapid oxidation processes in the bacterial cell metabolism (Rodríguez-López et al., 2018). However, presence of extracellular matrix in the biofilms formed by pathogenic bacteria usually provides greater resistance to biocides compared to its planktonic stage (Srey et al., 
2013). The mechanisms responsible for biofilm resistance to biocides are not entirely understood, although biofilms' specific architecture, decreased metabolic activity or the EPS composition have been hypothesised as possible reasons (Bridier et al., 2011). Therefore, routine assessments are recommended in the dairy industry environment to identify pathogens with the ability to produce biofilms on surfaces from materials commonly used for the manufacture of dairy products (Lee et al., 2014).

\section{Enzyme-based approaches for removal of biofilms}

In mature biofilms, the EPS formed comprises multiple types of molecules, including polysaccharides, DNA and proteins, although the complexity of EPS composition may vary markedly among the bacterial species (Combrouse et al., 2013). EPS has been considered an important target in sanitisation procedures for tackling biofilm problem in food processing environments (Sadekuzzaman et al., 2015). In this context, the use of enzyme-based preparations in combination with biocides offers an attractive approach to solve the problem of biofilms on surfaces in the dairy industry by the degradation of its matrix components, thus facilitating the inactivation and removal of detached cells during the industrial cleaning and disinfection procedures (Thallinger et al., 2013). Table 1 presents the primary outcomes of recent studies on the application of enzyme-based preparations for removal of microbial biofilms formed on different surfaces.

Proteases are the main class of enzymes showing high potential for removing bacterial biofilms and protein residues attached to internal surfaces of equipment such as vessels and pipes (Augustin et al., 2004). Examples include proteinase K, lysostaphin and aureolisin (Saggu et al., 2019). Proteases had greater activity on EPS degradation of biofilms formed by $P$. fluorescens than amylases (Srey et al., 2013). Glycosidases and deoxyribonuclease (DNAses) are also enzymes with potential activity for degradation of biofilms' EPS and release of planktonic cells (Saggu et al., 2019). Craigen et al. (2011) observed that DNAse I efficiently degraded the extracellular DNA of $S$. aureus biofilms, thus preventing the biofilm matrix's adhesion to the surface. However, practical applications of enzymes in the dairy industry are limited due to the high costs of enzyme-based preparations, especially when compared with traditional sanitisation methods with biocides, and variations in the enzymatic activities of different types of enzymes as reported in experimental studies (Augustin et al., 2004). By using metalloprotease secreted by Mycobacterium spp. SKS10, Saggu et al. (2019) observed an enzymatic degradation of nearly $62 \%$ in biofilm biomass and increased antibiotic accessibility inside the biofilm. Previously, Watters et al. (2016) demonstrated that $\alpha$-amylase, papain and bromelain almost wholly removed the biofilm formed by different strains (ATCC 25923, ATCC 33591, IQ0070, SA5214, SA5123 and SA5120) of $S$. aureus on polystyrene microplate.

The effect of DNAse I on dual-species biofilms formed by $L$. monocytogenes and $E$. coli on stainless steel coupons was reported by Rodríguez-López et al. (2016). The authors observed a reduction of nearly 2 log cycles in the bacterial counts for both species by DNAse I at 400 $\mu \mathrm{g} / \mathrm{mL}$. The removal of biofilms by DNAses is credited to the digestion of eDNA strand, leading to the destruction of biofilm matrix and cell death (Koohy et al., 2013). However, the role of eDNA as a structural component of biofilm matrix still needs clarification to completely elucidate the mode of action of DNAses for reducing bacterial cell adhesion in mature biofilms (Grande et al., 2011).

Several types of proteases have been studied against microbial biofilms, alone or in combination with other compounds. Araújo et al. (2017) observed reductions of 1.59 and $1.93 \log \mathrm{CFU} / \mathrm{cm}^{2}$ after treating $P$. fluorescens biofilms with protease alone or associated with cetyltrimethylammonium bromide, respectively. Complete elimination of biofilms formed by Macrococcus caseolyticus after 1.5 -h contact with protease $(500 \mathrm{mg} / \mathrm{mL})$ at $45^{\circ} \mathrm{C}$ was reported by Mnif et al. (2020). Combination of proteases with surfactants and phenoxyethanol against biofilms L. monocytogenes provided a cell count reduction of $6.9 \log \mathrm{CFU} / \mathrm{cm}^{2}$ (Mazaheri et al., 2020). The application of proteinase $\mathrm{K}$ against biofilms of $E$. coli O157:H7 resulted in higher efficacy than other enzymes such as DNAse I and cellulose, leading to 91-99\% biofilm mass reductions, equivalent to $2.43 \log \mathrm{CFU} / \mathrm{cm}^{2}$ (Lim et al., 2019). However, Wang et al. (2016) observed a lower percentage reduction (55\%) by proteinase $\mathrm{K}$ against biofilms of Salmonella spp., indicating species-specific variations in the efficacy of this enzyme.

Another protease frequently tested against biofilms is papain (from Papaya carica), which can be attributed to its high proteolytic capacity, broad spectrum against protein substrates and the ability to hydro led these proteins into small peptides and amino acids (Borrajo et al., 2020; Sáringer et al., 2019). Song et al. (2020) observed that papain at $5.0 \mu \mathrm{g} / \mathrm{mL}$ resulted in $26.1,21.6$ and $50.9 \%$ reductions in the biofilm mass formed by $S$. aureus, $C$. jejuni NCTC 11168 and C. jejuni Y23-5, respectively. Accordingly, Mohamed et al. (2018) demonstrated that $100 \mathrm{mg} / \mathrm{mL}$ of papain removed 59\% of biofilms formed by Klebsiella pneumoniae, although no effects on planktonic cells were observed.

Amylases represent an expressive group tested in enzymatic cleaning procedures, among which the main types 
Table 1. Recent studies on the application of enzyme-based preparations for the removal of microbial biofilms formed on different surfaces.

\begin{tabular}{|c|c|c|c|c|}
\hline Enzyme preparation & $\begin{array}{l}\text { Microorganism/biofilm } \\
\text { formation }\end{array}$ & Experimental conditions & Main effects & Reference \\
\hline $\begin{array}{l}\beta \text {-glucanase, } \alpha \text {-amylase, lipase } \\
\text { and protease, associated } \\
\text { with cetyltrimethylammonium } \\
\text { bromide (CTAB) }\end{array}$ & $\begin{array}{l}P \text {. fluorescens grown on } \\
\text { bioreactor I (containing } \\
\text { stainless steel surface) } \\
\text { and dripped on bioreac- } \\
\text { tor II at } 30^{\circ} \mathrm{C} \text { for } 7 \text { days. }\end{array}$ & $\begin{array}{l}\text { Enzymatic solutions or CTAB } \\
\text { applied through flow cells for } \\
1 \mathrm{~h} \text {, and evaluated after } 2,12 \\
\text { and } 24 \mathrm{~h} \text {. }\end{array}$ & $\begin{array}{l}\text { Protease obtained a greater } \\
\text { cell reduction ( } 1.59 \text { log CFU/ } \\
\left.\mathrm{cm}^{2}\right) \text { than lipase, } \beta \text {-glucanase } \\
\text { and } \alpha \text {-amylase }(1.34,1.25 \text { and } \\
1.09 \text { log CFU/cm² respectively). } \\
\text { Protease associated with CTAB } \\
\text { reduced } 1.93 \text { log CFU/cm. }{ }^{2}\end{array}$ & $\begin{array}{l}\text { Araújo et al., } \\
2017\end{array}$ \\
\hline $\begin{array}{l}\text { Pronase, cellulase, pectinase, } \\
\text { DNAse I, lysozyme, phospholi- } \\
\text { pase, peroxidase, } \beta \text {-glucanase } \\
\text { and chitinase }\end{array}$ & $\begin{array}{l}\text { L. monocytogenes } \\
\text { mono-species and } \\
\text { dual-species biofilms } \\
\text { grown on stainless steel } \\
\text { coupons at } 25^{\circ} \mathrm{C} \text { for } \\
48 \mathrm{~h} \text {. }\end{array}$ & $\begin{array}{l}1 \mathrm{~mL} \text { of mixed-enzymes solu- } \\
\text { tion applied on the stainless } \\
\text { steel coupons with biofilms at } \\
\text { room temperature for } 1 \mathrm{~h} \text {. }\end{array}$ & $\begin{array}{l}\text { L. monocytogenes cells } \\
\text { mono-species biofilms reduced } \\
\text { nearly } 1 \text { log cycle. In dual-spe- } \\
\text { cies biofilms, only moderate } \\
\text { effects were observed. }\end{array}$ & $\begin{array}{l}\text { Puga et al., } \\
2018\end{array}$ \\
\hline Papain (from C. papaya) & $\begin{array}{l}\text { K. pneumoniae grown } \\
\text { on plates at } 37^{\circ} \mathrm{C} \text { for } \\
24 \mathrm{~h} \text {. }\end{array}$ & $\begin{array}{l}\text { Papain at } 3.125,6.25,12.5 \text {, } \\
25,50 \text { and } 100 \mathrm{mg} / \mathrm{mL} \text { tested } \\
\text { against planktonic cells and } \\
\text { during biofilm formation. }\end{array}$ & $\begin{array}{l}\text { No bactericidal effect was } \\
\text { observed. The highest level } \\
\text { (100 mg/mL) reduced } 55-59 \% \\
\text { of biofilm mass. }\end{array}$ & $\begin{array}{l}\text { Mohamed } \\
\text { et al., } 2018\end{array}$ \\
\hline $\begin{array}{l}\text { Metalloprotease (from } \\
\text { Mycobacterium spp. (SKS10) }\end{array}$ & $\begin{array}{l}\text { S. aureus MTCC } 11949 \\
\text { grown on polystyrene } \\
\text { surface at } 37^{\circ} \mathrm{C} \text { for } 72 \mathrm{~h} .\end{array}$ & $\begin{array}{l}\text { Metalloprotein dissolved in } \\
\text { Luria-Bertani broth at } 10 \text {, } \\
100 \text { or } 1,000 \mu \mathrm{g} / \mathrm{mL} \text {, and } \\
\text { incubated with biofilms for } \\
24 \text { h at } 37^{\circ} \mathrm{C} \text {. }\end{array}$ & $\begin{array}{l}\text { The enzyme degraded } \geq 62 \% \\
\text { of biofilm biomass, starting } \\
\text { from } 10 \mu \mathrm{g} / \mathrm{mL} \text {. Increased } \\
\text { accessibility of antibiotics inside } \\
\text { the biofilm was also observed. }\end{array}$ & $\begin{array}{l}\text { Saggu et al., } \\
2019\end{array}$ \\
\hline $\begin{array}{l}\text { DNAse I, proteinase } \mathrm{K} \text { and } \\
\text { cellulase }\end{array}$ & $\begin{array}{l}\text { E. coli } 0157: \mathrm{H} 7 \text { grown } \\
\text { on polystyrene and } \\
\text { stainless steel at } 25^{\circ} \mathrm{C} \\
\text { for } 24 \mathrm{~h} \text {. }\end{array}$ & $\begin{array}{l}\text { Cellulase }(20 \mathrm{mg} / \mathrm{mL}) \text {, } \\
\text { proteinase } \mathrm{K}(10 \mathrm{mg} / \mathrm{mL}) \text { and } \\
\text { DNAse I }(1 \mathrm{mg} / \mathrm{mL}) \text { incubated } \\
\text { with biofilms on polystyrene } \\
\text { plates }\left(25^{\circ} \mathrm{C}, 24 \mathrm{~h}\right) \text { and stain- } \\
\text { less steel }\left(37^{\circ} \mathrm{C}, 1 \mathrm{~h}\right) \text {. }\end{array}$ & $\begin{array}{l}\text { Proteinase } \mathrm{K} \text { and cellulase } \\
\text { reduced } 91-99 \% \text { and } 65-98 \% \\
\text { of biofilm mass, respectively. } \\
\text { Proteinase } \mathrm{K} \text { treatment resulted } \\
\text { in greater reduction of biofilm } \\
\text { cells }\left(2.43 \log \mathrm{CFU} / \mathrm{cm}^{2}\right) \text {. }\end{array}$ & $\begin{array}{l}\text { Lim et al., } \\
2019\end{array}$ \\
\hline $\begin{array}{l}\text { Endolysin LysCSA13 secreted } \\
\text { by S. aureus }\end{array}$ & $\begin{array}{l}\text { S. aureus RN4220 and } \\
\text { CCARM } 3090 \text { grown } \\
\text { on polystyrene plates, } \\
\text { stainless steel and glass } \\
\text { surface at } 37^{\circ} \mathrm{C} \text { for } 24 \mathrm{~h} \text {. }\end{array}$ & $\begin{array}{l}\text { Endolysin LysCSA13 } \\
\text { solutions (100, } 300 \text { and } 1000 \\
n M) \text { incubated with biofilms } \\
\text { on polystyrene ( } 2 \mathrm{~h}) \text {, stainless } \\
\text { steel }(1 \mathrm{~h}) \text { and glass }(2 \mathrm{~h}) \text {. }\end{array}$ & $\begin{array}{l}\text { Endolysin LyCAS13 at levels } \\
\bigotimes 300 \mathrm{nM} \text { reduced } 82-84 \% \text { of } \\
\text { biofilm mass on all surfaces } \\
\text { tested. }\end{array}$ & $\begin{array}{l}\text { Cha et al., } \\
2019\end{array}$ \\
\hline $\begin{array}{l}\text { Proteases in combination } \\
\text { with ethoxylated sodium } \\
\text { lauryl ether glycolate, } \mathrm{N} \text {-oxide } \\
\mathrm{N}, \mathrm{N} \text {-dimethyl-C12-C14- } \\
\text { alkylamine, anionic and } \\
\text { non-ionic surfactants and } \\
\text { phenoxyethanol }\end{array}$ & $\begin{array}{l}\text { L. monocytogenes } \\
\text { grown on stainless steel } \\
\text { coupons at } 30^{\circ} \mathrm{C} \text { for } 7 \\
\text { days. }\end{array}$ & $\begin{array}{l}\text { Enzyme-detergent solution } \\
(3 \mathrm{~mL}) \text { was added to biofilms } \\
\text { and kept at } 50^{\circ} \mathrm{C} \text { for } 15 \mathrm{~min} \text {. }\end{array}$ & $\begin{array}{l}\text { Maximum reduction of } 6.9 \text { log } \\
\mathrm{CFU} / \mathrm{cm}^{2} \text { in the biofilm cells, } \\
\text { corresponding to } 85-99 \% \text { of } \\
\text { biomass reduction. }\end{array}$ & $\begin{array}{l}\text { Mazaheri } \\
\text { et al., } 2020\end{array}$ \\
\hline $\begin{array}{l}\text { Mannanase, savinase and } \\
\alpha \text {-amylase in combination with } \\
\text { thymol and cinnamaldehyde }\end{array}$ & $\begin{array}{l}\text { L. monocytogenes } \\
\text { grown on stainless steel } \\
\text { coupons at } 30^{\circ} \mathrm{C} \text { for } 7 \\
\text { days. }\end{array}$ & $\begin{array}{l}\text { Three consecutive treatments } \\
\text { of biofilms with the enzyme- } \\
\text { based preparation at } 50^{\circ} \mathrm{C} \text { for } \\
20 \text { min. }\end{array}$ & $\begin{array}{l}\text { Reduction of } 75-98 \% \text { in the } \\
\text { biofilm biomass. }\end{array}$ & $\begin{array}{l}\text { Ripolles-Avila } \\
\text { et al., } 2020\end{array}$ \\
\hline Papain (from C. papaya) & $\begin{array}{l}\text { S. aureus and C. jejuni } \\
\text { (NCTC } 11168 \text { and } \\
\text { Y23-5) grown on } \\
\text { polystyrene microtiter } \\
\text { plates for } 24 \mathrm{~h} \text { and } 72 \mathrm{~h} \\
\text { at } 37^{\circ} \mathrm{C} \text {, respectively. }\end{array}$ & $\begin{array}{l}\text { Papain }(0.31-5.0 \mu \mathrm{g} / \mathrm{mL}) \\
\text { added on biofilms and incu- } \\
\text { bated at } 37^{\circ} \mathrm{C} \text { for } 24 \mathrm{~h} \\
\text { (S. aureus) and } 72 \mathrm{~h} \\
\text { (C. jejuni). }\end{array}$ & $\begin{array}{l}\text { Degradation of mature } \\
\text { biofilms by papain at } 5.0 \mu \mathrm{g} / \\
\mathrm{mL} \text { with } 22-26 \% \text { and } 22-51 \% \\
\text { reduction in biofilm biomass } \\
\text { from S. aureus and C. jejuni, } \\
\text { respectively }\end{array}$ & $\begin{array}{l}\text { Song et al., } \\
2020\end{array}$ \\
\hline $\begin{array}{l}\text { Protease, lipase, amylase, } \\
\text { CMCase and DNAse }\end{array}$ & $\begin{array}{l}\text { M. caseolyticus grown } \\
\text { on polystyrene micro- } \\
\text { plates and stainless } \\
\text { steel surfaces at } 30^{\circ} \mathrm{C} \\
\text { for } 24 \mathrm{~h}\end{array}$ & $\begin{array}{l}\text { Pronase, CMCase, } \\
\text { amylase and lipase at } \\
62.5-500 \mathrm{mg} / \mathrm{mL} \text {, and DNAse } \\
\text { at } 7.8-62.5 \mathrm{mg} / \mathrm{mL} \text {, incubated } \\
\text { with biofilms at } 45^{\circ} \mathrm{C} \text { for } 1.5 \mathrm{~h} \text {. }\end{array}$ & $\begin{array}{l}\text { DNAse, protease and lipase } \\
\text { at their highest concentra- } \\
\text { tions eliminated the biofilms. } \\
\text { CMCase and amylase did not } \\
\text { affect biofilms. }\end{array}$ & $\begin{array}{l}\text { Mnif et al., } \\
2020\end{array}$ \\
\hline
\end{tabular}


studied are $\alpha$-amylase and glucoside amylase, representing about $25 \%$ of the world market for enzyme commercialisation (Sundarram and Murthy, 2014). These enzymes catalyse hydrolysis reactions in the $\alpha-1,4$-glycosidic bonds of starch, thus producing glucose and maltose (Sundarram and Murthy, 2014). Araújo et al. (2017) observed that $\alpha$-amylase reduced counts in the biofilms of $P$. fluorescensin by nearly $1.1 \mathrm{log} \mathrm{CFU} / \mathrm{cm}^{2}$. Recent evidence has indicated that combinations of $\alpha$-amylase with thymol, cinnamaldehyde and other enzymes, such as mannanase and savinase, were highly significant (75-98\% reductions in the biomass) against the biofilms formed by L. monocytogenes (Ripolles-Avila et al., 2020). However, amylases at levels as high as $500 \mathrm{mg} / \mathrm{mL}$ were not effective against the biofilms formed by Macrococcus caseolyticus (Mnif et al., 2020).

Recently, cellulases and lipases have been studied alone or in an association against biofilms and removing residual food materials from surfaces. Guerrero-Navarro et al. (2019) found that the association of lipase, amylase and protease removed $78 \%$ of milk fouling from stainless steel surfaces after enzymatic treatment. Regarding removal of biofilms by lipases, Araújo et al. (2017) reported a reduction of $1.34 \log \mathrm{CFU} / \mathrm{cm}^{2}$ of biofilms from P. fluorescens, while complete elimination of $M$. caseolyticus biofilms was described by Mnif et al. (2020). Cellulase at a concentration of $1-20 \mathrm{mg} / \mathrm{mL}$ led to reductions of $5.0 \log \mathrm{CFU} / \mathrm{cm}^{2}$ of biofilm cells from several serotypes of Salmonella enterica (S. Typhimurium, S. Enteritidis, $S$. Infantis, S. Stanley, S. Agona, S. Derby and S. Indiana) (Wang et al., 2016). Similar results were reported by Lim et al. (2019), who found that cellulase at $20 \mathrm{mg} / \mathrm{mL}$ reduced $65-98 \%$ of the biofilm mass formed by E. coli O157:H7, thus confirming the potential application of this enzyme against biofilms.

\section{Concluding Remarks}

As communities of microorganisms, biofilms adhere to several types of surfaces to guarantee their survival under stress conditions in the environment. Among the main pathogenic microorganisms listed as problems for the dairy industry are L. monocytogenes, S. aureus, B. cereus, Salmonella spp. and E.coli. As mature biofilms have increased resistance to biocides, enzyme-based preparations have been studied aiming at their potential use as aiding agents for removal of biofilms. Among the main groups of enzymes studied, proteases, amylases, cellulases and DNAses show perspectives for degradation of biofilm matrix components, reducing 1.0-6.9 log CFU/ $\mathrm{cm}^{2}$ of the aforementioned pathogens in mature biofilms and up to $99 \%$ of their biofilm biomass. These features increase perspectives for the application of enzymebased preparations alone or associated with biocides for cleaning equipment, utensils and other surfaces in dairy processing environments. Further studies are needed to define potential combinations of the most effective enzymes and sanitisers that are efficient and economically viable for application in dairy industries.

\section{Acknowledgements}

The authors thank the Conselho Nacional de Desenvolvimento Científico e Tecnológico (CNPq, Grant 306304/2017-1) for financial support. This study was financed in part by the Coordenação de Aperfeiçoamento de Pessoal de Nível Superior-Brasil (CAPES), finance code 001.

\section{References}

Ahmed, A.M. and Shimamoto, T., 2014. Isolation and molecular characterization of Salmonella enterica, Escherichia coli O157:H7 and Shigella spp. from meat and dairy products in Egypt. International Journal of Food Microbiology 168: 57-62. https://doi.org/10.1016/j.ijfoodmicro.2013.10.014.

Akrami-Mohajeri, F., Derakhshan, Z., Ferrante, M., Hamidiyan, N., Soleymani, M., Conti,G.O., et al., 2018. The prevalence and antimicrobial resistance of Listeria spp in raw milk and traditional dairy products delivered in Yazd, central Iran (2016). Food and Chemical Toxicology 114: 141-144. https://doi.org/10.1016/j. fct.2018.02.006

Alonso, V.P.P. and Kabuki, D.Y., 2019. Formation and dispersal of biofilms in dairy substrates. International Journal of Dairy Technology 70: 1-6. https://doi.org/10.1111/1471-0307.12587

Araújo, P.A., Machado, I., Meireles, A., Leikness, T., Mergulhão, F., Melo, L.F. et al., 2017. Combination of selected enzymes with cetyltrimethylammonium bromide in biofilm inactivation, removal and regrowth. Food Research International 95: 101107. https://doi.org/10.1016/j.foodres.2017.02.016

Assaf, J.C., El Khoury, A., Chokr, A., Louka, N. and Atoui, L., 2019. A novel method for elimination of aflatoxin $M_{1}$ in milk using Lactobacillus rhamnosus GG biofilm. International Journal of Dairy Technology 72: 248-256. https://doi. org/10.1111/1471-0307.12578

Augustin, M., Ali-Vehmas, T. and Atroshi, F., 2004. Assessment of enzymatic cleaning agents and disinfectants against bacterial biofilms. Journal of Pharmacy and Pharmaceutical Sciences 7: 55-64. Available at: https://sites.ualberta.ca/ CSps/JPPS7(1)/F. Atroshi/biofilm.pdf

Borrajo, P., Pateiro, M., Gagaoua, M., Franco, D., Zhang, W. and Lorenzo, J.M., 2020. Evaluation of the antioxidant and antimicrobial activities of porcine liver protein hydrolysates obtained using alcalase, bromelain, and papain. Applied Sciences 10: 2290. https://doi.org/10.3390/app10072290

Bottone, E.J., 2010. Bacillus cereus, a volatile human pathogen. Clinical Microbiology Review 23: 382-398. https://doi. org/10.1128/CMR.00073-09 
Bridier, A., Briandet, R., Thomas, V. and Dubois-Brissonnet, F., 2011. Resistance of bacterial biofilms to disinfectants: a review. Biofouling 27: 1017-1032. https://doi.org/10.1080/08927014.20 11.626899

Cha, Y., Son, B. and Ryu, S., 2019. Effective removal of staphylococcal biofilms on various food contact surfaces by Staphylococcus aureus phage endolysin LysCSA13. Food Microbiology 84: 103245. https://doi.org/10.1016/j.fm.2019.103245

Chen, Y., Burall, L.S., Macarisin, D., Pouillot, R., Strain, E., De Jesus, A.J., et al., 2016. Prevalence and level of Listeria monocytogenes in ice cream linked to a listeriosis outbreak in the United States. Journal of Food Protection 79: 1828-1832. https://doi. org/10.4315/0362-028x.jfp-16-208

Cherif-Antar, A., Moussa-Boudjemâa, B., Didouh, N., Medjahdi, K., Mayo, B. and Flórez, A B., 2016. Diversity and biofilm-forming capability of bacteria recovered from stainless steel pipes of a milk-processing dairy plant. Dairy Science and Technology 96: 27-38. https://doi.org/10.1007/s13594-015-0235-4

Colagiorgi, A., Bruini, I., Di Ciccio, P.A., Zanardi, E., Ghidii, S. and Ianieri, A., 2017. Listeria monocytogenes biofilms in the wonderland of food industry. Pathogens 6: 41. https://doi.org/10.3390/ pathogens6030041

Combrouse, T., Sadovskaya, I., Faille, C., Kol, O., Guérardel, Y. and Midelet-Bourdin, G., 2013. Quantification of the extracellular matrix of the Listeria monocytogenes biofilms of different phylogenic lineages with optimization of culture conditions. Journal of Applied Microbiology 114: 1120-1131. https://doi. org/10.1111/jam.12127

Coughlan, L.M., Cotter, P.D., Hill, C. and Alvarez-Ordóñez, A., 2016. New weapons to fight old enemies: novel strategies for the (bio) control of bacterial biofilms in the food industry. Frontiers in Microbiology 7: 1641. https://doi.org/10.3389/fmicb.2016. 01641

Craigen, B., Dashiff, A. and Kadouri D.E., 2011. The use of commercially available alpha-amylase compounds to inhibit and remove Staphylococcus aureus biofilms. The Open Microbiology Journal 5: 21-31. https://doi:10.2174/1874285801105010021

Cusato, S., Gameiro, A.H., Sant'ana, A.S., Corassin, C.H., Cruz, A.G., Faria, J.A.F. and Oliveira, C.A.F., 2014. Assessing the costs involved in the implementation of GMP and HACCP in a small dairy factory. Quality Assurance and Safety of Crops \& Foods 6: 135-139. https://doi.org/10.3920/QAS2012.0195

Di Ciccio, P., Vergara, A., Festino, A.R., Paludi, D., Zanardi, E., Ghidini, S. and Ianieri, A., 2015. Biofilm formation by Staphylococcus aureus on food contact surfaces: relationship with temperature and cell surface hydrophobicity. Food Control 50: 930-936. https://doi.org/10.1016/j.foodcont.2014.10.048

Dominciano, L.C.C., Lee, S.H.I., Corassin, C.H., De Martinis, E.C.P. and Oliveira, C.A.F., 2016. Effects of oleuropein and peracetic acid as sanitizing agents for inactivation of Listeria monocytogenes biofilms. The Open Conference Proceedings Journal 7: 1-6. https://doi.org/10.2174/2210289201607010001

Ehling-Schulz, M., Lereclus, D. and Koehler, T.M., 2019. The Bacillus cereus group: Bacillus species with pathogenic potential. Microbiology Spectrum 7: 875-902. https://doi. org/10.1128\%2Fmicrobiolspec.GPP3-0032-2018
Fleming, H.C., Wingender, J., Szewzyk, U., Steinberg, P., Rice, S.A. and Kjelleberg, S., 2016. Biofilms: an emergent form of bacterial life. Nature Reviews Microbiology 14: 563-575. https://doi. org/10.1038/nrmicro.2016.94

Gopal, N., Ross, P.R., Beresford, T.P., Fenelon, M.A. and Cotter, P.D., 2015. The prevalence and control of Bacillus and related spore-forming bacteria in the dairy industry. Frontiers in Microbiology 6: 1418. https://doi.org/10.3389/fmicb.2015.01418

Grande, R., Di Giulio, M., Bessa, L.J., Di Campli, E., Baffoni, M., Guarnieri, S. et al., 2011. Extracellular DNA in Helicobacter pylori biofilm: a backstairs rumor. Journal of Applied Microbiology 110: 490-498. https://doi.org/10.1111/j.1365-2672.2010.04911.x Guerrero-Navarro, A.E., Rios-Castillo, A.G., Ripolles-Avilla, C., Hascoet, A.S., Felipe, X. and Rodriguez-Jereza, J.J., 2019. Development of a dairy fouling model to assess the efficacy of cleaning procedures using alkaline and enzymatic products. Food Science and Technology 106: 44-49. https://doi. org/10.1016/j.lwt.2019.02.057

Gutiérrez, D., Delgado, S., Vázquez-Sánchez, D., Martínez, B., Cabo, M.L., Rodríguez, A., et al., 2012. Incidence of Staphylococcus aureus and analysis of associated bacterial communities on food industry surfaces. Applied and Environmental Microbiology 78: 8547-8554. https://doi.org/10.1128/AEM.02045-12

Høiby, N., 2017. A short history of microbial biofilms and biofilm infections. Journal of Pathology, Microbiology and Immunology 125: 272-275. https://doi.org/10.1111/apm.12686

Hooshdar, P., Kermanshahi, R.K., Ghadam, P. and KhosraviDarani, K., 2020. A review on production of exopolysaccharide and biofilm in probiotics like lactobacilli and methods of analysis. Biointerface Research in Applied Chemistry 10: 6058-6075. https://doi.org/10.33263/BRIAC105.60586075

Jakobsen, R.A., Heggebø, R., Sunde, E.B. and Skjervheim, M., 2011. Staphylococcus aureus and Listeria monocytogenes in Norwegian raw milk cheese production. Food Microbiology 3: 492-496. https://doi.org/10.1016/j.fm.2010.10.017

Jamali, H., Paydar, M., Radmehr, B., Ismail, S. and Dadrasnia, A., 2015. Prevalence and antimicrobial resistance of Staphylococcus aureus isolated from raw milk and dairy products. Food Control 54: 383-388. https://doi.org/10.1016/j.foodcont.2015.02.013

Jeong, D., Kim, D.-H., Song, K.-Y. and Seo, K.-H., 2018. Antimicrobial and anti-biofilm activities of Lactobacillus kefiranofaciens DD2 against oral pathogens. Journal of Oral Microbiology 10: 1472985. https://doi.org/10.1080/20002297.2 018.1472985

Kadam, S.R., Besten, H.M.W., Veen, S., Zwieteringb, M.H., Moezelaar, R. and Abee, T., 2013. Diversity assessment of Listeria monocytogenes biofilm formation: impact of growth condition, serotype and strain origin. International Journal of Food Microbiology 165: 259-264. https://doi.org/10.1016/j. ijfoodmicro.2013.05.025

Kim, N.-N., Kim, W.J. and Kang, S.-S., 2019. Anti-biofilm effect of crude bacteriocin derived from Lactobacillus brevis DF01 on Escherichia coli and Salmonella Typhimurium. Food Control 98: 274-280. https://doi.org/10.1016/j.foodcont.2018.11.004.

Koohy, H., Down, T.A. and Hubbard, T.J., 2013. Chromatin accessibility data sets show bias due to sequence specificity of the 
DNAse I enzyme. PLoS One 8: 1-9. https://doi.org/10.1371/ journal.pone.0069853

Kwon, M., Hussain, M.S. and Oh, D.H., 2017. Biofilm formation of Bacillus cereus under food-processing-related conditions. Food Science and Biotechnology 26: 1103-1111. https://doi. org/10.1007/s10068-017-0129-8

Lee, S.H.I., Barancelli, G.V., Camargo, T.M., Corassin, C.H., Rosim, R.E., Cruz, A.G., et al., 2017a. Biofilm-producing ability of Listeria monocytogenes isolates from Brazilian cheese processing plants. Food Research International 91: 88-91. https:// doi.org/10.1016/j.foodres.2016.11.039

Lee, S.H.I., Barancelli, G.V., Rosim, R.E., Corassin, C.H., Coppa, C.F.S.C. and Oliveira, C.A.F., 2017b. Effect of peracetic acid on biofilms formed by Listeria monocytogenes strains isolated from a Brazilian cheese processing plant. Brazilian Journal of Pharmaceutical Sciences 53: 1-7. http://doi.org/10.1590/ s2175-97902017000300071

Lee, S.H.I., Cappato, L.P., Corassin, C.H., Cruz, A.G. and Oliveira, C.A.F., 2016. Effect of peracetic acid on biofilms formed by Staphylococcus aureus and Listeria monocytogenes isolated from dairy plants. Journal of Dairy Science 99: 23842390. https://doi.org/10.3168/jds.2015-10007

Lee, S.H.I., Mangolin, B.L.C., Gonçalves, J.L., Neef, D.V., Silva, M.P., Cruz, A.G. et al., 2014. Biofilm-producing ability of Staphylococcus aureus isolates from Brazilian dairy farms. Journal of Dairy Science 97: 1812-1816. https://doi.org/10.3168/ jds.2013-7387

Lim, E.S., Koo, O.K., Kim, M.J. and Kim, J.-S., 2019. Bio-enzymes for inhibition and elimination of Escherichia coli O157:H7 bioflm and their synergistic effect with sodium hypochlorite. Scientific Reports 9: 9920. https://doi.org/10.1038/s41598-019-46363-w

Mansouri-Najand, L., Kianpour, M., Sami, M. and Jajarmi, M., 2015. Prevalence of Listeria monocytogenes in raw milk in Kerman, Iran. Veterinary Research Forum 6: 223-226. Available at: https://www. ncbi.nlm.nih.gov/pmc/articles/PMC4611976/pdf/vrf-6-223.pdf

Marchand, S., De Block, J., De Jonghe, A., Coorevits, A., Heyndrickx, M. and Herman, L., 2012. Biofilm formation in milk production and processing environments; influence on milk quality and safety. Comprehensive Reviews in Food Science and Food Safety 11: 133-147. https://doi.org/10.1111/j.1541-4337.2011.00183.x

Mazaheri, T., Ripolles-Avilla, C., Hascoet, A.S. and RodriguezJerez, J.J., 2020. Effect of an enzymatic treatment on the removal of mature Listeria monocytogenes biofilms: a quantitative and qualitative study. Food Control 114: 107266. https://doi. org/10.1016/j.foodcont.2020.107266

Meng, L., Zhang, Y., Liu, H., Zhao, S., Wang, J. and Zheng, N., 2017. Characterization of Pseudomonas spp. and associated proteolytic properties in raw milk stored at low temperatures. Frontiers in Microbiology 8: 2158. https://doi.org/10.3389/ fmicb.2017.02158

Mnif, S., Jardak, M., Yaich, A. and Aifa, S., 2020. Enzyme-based strategy to eradicate monospecies Macrococcus caseolyticus biofilm contamination in dairy industries. International Dairy Journal 100: 104560. https://doi.org/10.1016/j.idairyj.2019.104560

Mohamed, S.H., Mohamed, M.S.M., Khalil, M.S., Mohamed, W.S. and Mabrouk, M.I., 2018. Antibiofilm activity of papain enzyme against pathogenic Klebsiella pneumoniae. Journal of Applied Pharmaceutical Science 8: 163-168. https://doi.org/0.7324/ japs.2018.8621

Mullan, W.M.A., 2019. Are we closer to understanding why viable cells of Mycobacterium avium subsp. paratuberculosis are still being reported in pasteurized milk? International Journal of Dairy Technology 72: 332-344. https://doi.org/10.1111/1471-0307.12617

Nahar, S., Mizan, M.K.R., Ha, A. J.-W. and Ha, S.-D., 2018. Advances and future prospects of enzyme-based biofilm prevention approaches in the food industry. Comprehensive Reviews in Food Science and Food Safety 17: 1484-1502. https://doi. org/10.1111/154.1-4337.12382

Owusu-Kwarteng, J., Wuni, A., Akabanda, F., Tano-Debrah, K. and Jespersen, L., 2017. Prevalence, virulence factor genes and antibiotic resistance of Bacillus cereussensu lato isolated from dairy farms and traditional dairy products. BMC Microbiology 17: 65 . https://doi.org/10.1186/s12866-017-0975-9

Oxaran, V., Dittmann, K.K., Lee, S.H.I., Chaul, L.T., Oliveira, C.A.F., Corassin, C.H., et al., 2018. Behavior of foodborne pathogens, Listeria monocytogenes and Staphylococcus aureus, in mixed-species biofilm exposed to biocides. Applied and Environmental Microbiology 84: e020038-18. https://doi. org/10.1128/AEM.02038-18

Puga, C.H., Rodríguez-Lopez, P., Cabo, M.L., SanJose, C. and Orgaz, B., 2018. Enzymatic dispersal of dual-species biofilms carrying Listeria monocytogenes and other associated food industry bacteria. Food Control 94: 222-228. https://doi. org/10.1016/j.foodcont.2018.07.017

Ripolles-Avila, C., Ramos-Rubio, M., Hascoet, A.S., Castillo, M. and Rodriguez-Jerez, J.J., 2020. New approach for the removal of mature biofilms formed by wild strains of Listeria monocytogenes isolated from food contact surfaces in an Iberian pig processing plant. International Journal of Food Microbiology 323: 108595. httpshttps://doi.org/10.1016/j.ijfoodmicro.2020.108595

Rodríguez-López, P., Carballo-Justo, A., Draper, L.A. and Cabo, M.L., 2016. Removal of Listeria monocytogenes dualspecies biofilms using combined enzyme benzalkonium chloride treatments. Biofouling 33: 45-58. https://doi.org/10.1080/08927 014.2016.1261847

Rodríguez-López, P., Rodriguez-Herrera, J.J., Vazquez-Sanchez, D. and Cabo, M.L., 2018. Current knowledge on Listeria monocytogenes biofilms in food-related environments: incidence, resistance to biocides, ecology and biocontrol. Foods 7: 85. https:// doi.org/10.3390/foods7060085

Rossi, C., Serio, A., Chaves-López, C., Anniballi, F., Auricchi, B., Goffredo, E. et al., 2018. Biofilm formation, pigment production and motility in Pseudomonas spp. isolated from the dairy industry. Food Control 86: 241-248. https://doi.org/10.1016/j. foodcont.2017.11.018

Ryser, E.T., 2011. Pathogens in milk: Listeria monocytogenes. In: Fuquay, J.W. (ed.) Encyclopedia of dairy sciences, 2nd ed. Academic Press, London, pp. 1650-1655.

Sadekuzzaman, M., Yang, S., Mizan, M.F.R. and Ha, S.D., 2015. Current and recent advanced strategies for combating biofilms. Comprehensive Reviews in Food Science and Food Safety 14: 491-509. https://doi.org/10.1111/1541-4337.12144. 
Saggu, S.K., Jha, G. and Mishra, P.C., 2019. Enzymatic degradation of biofilm by metalloprotease from Microbacterium sp. Sks10. Frontiers in Bioengineering and Biotechnology 7: 192. https:// doi.org/10.3389/fbioe.2019.00192

Sáringer, S., Akula, R.A., Szerlauth, A. and Szilagy, I., 2019. Papain adsorption on latex particles: charging, aggregation, and enzymatic activity. The Journal of Physical Chemistry B 123: 99849991. https://doi.org/10.1021/acs.jpcb.9b08799

Shi, X. and Zhu, X., 2009. Biofilm formation and food safety in food industries. Trends in Food Science and Technology 20: 407-413. https://doi.org/10.1016/j.tifs.2009.01.054

Silva, E.P. and De Martinis, E.C., 2013. Current knowledge and perspectives on biofilm formation: the case of Listeria monocytogenes. Applied Microbiology and Biotechnology 97: 957-968. https://doi.org/10.1007/s00253-012-4611-1

Song, Y.J., Yu, H.H., Kim, Y.J., Lee, N.-K. and Paik, H.-D., 2020. The use of papain for the removal of biofilms formed by pathogenic Staphylococcus aureus and Campylobacter jejuni. Food Science and Technology 127: 109383. https://doi.org/10.1016/j. lwt.2020.109383

Srey, S., Jahid, I.K. and Ha, S.D., 2013. Biofilm formation in food industries: a food safety concern. Food Control 31: 572-585. https://doi.org/10.1016/j.foodcont.2012.12.001

Sundarram, A. and Murthy, T.P.K., 2014. $\alpha$-Amylase production and applications: a review. Journal of Applied and Environmental Microbiology 2: 166-175. https://doi.org/10.12691/jaem-2-4-10
Thallinger, B., Prasetyo, E.N., Nyanhongo, G.S. and Guebitz, G.M., 2013. Antimicrobial enzymes: an emerging strategy to fight microbes and microbial biofilms. Biotechnology Journal 8: 97-109. https://doi.org/10.1002/biot.201200313

Unlu, A., Sar, T., Seker, G., Erman, A.G., Kalpar, E. and Akbas, M.Y., 2018. Biofilm formation by Staphylococcus aureus strains and their control by selected phytochemicals. International Journal of Dairy Technology 71: 637-646. https://doi. org/10.1111/1471-0307.12520

Vidic, J., Chaix, C., Manzano, M. and Heyndrickx, M., 2020. Food sensing: detection of Bacillus cereus spores in dairy products. Biosensors 10: 15. https://doi.org/10.3390/bios10030015

Wang, H., Wang, H., Xing, T., Wu, N., Xu, X. and Zhou, G., 2016. Removal of Salmonella biofilm formed under meat processing environment by surfactant in combination with bio-enzyme. Food Science and Technology 66: 298-304. https://doi. org/10.3389/fmicb.2018.00898

Watters, C., Burton, T., Kirui, D.K. and Millenbaugh, N.J., 2016. Enzymatic degradation of in vitro Staphylococcus aureus biofilms supplemented with human plasma. Infection and Drug Resistance 9: 71-78. https://doi.org/10.2147/IDR.S103101

Yeganeh, M., Hosseini, H., Mehrabian, S., Torbati, E.S. and Zamir, S.M., 2017. Antibiofilm effects of Lactobacilli against ciprofloxacin-resistant uropathogenic Escherichia coli strains in pasteurized milk. Applied Food Biotechnology 4: 241-250. https://doi.org/10.22037/afb.v4i3.15014. 